\title{
Analysis of Empty Containers Supplies in the Shipping Network: Case Study at National Shipping Company
}

\author{
Heri Cahyono $^{1}$ and I Nyoman Pujawan ${ }^{1}$
}

\begin{abstract}
National Shipping Company (NSC) is a national shipping lines servicing domestic routes and a logistic key player of sea transport in Indonesia. Focus of this research is to determine total containers inventory for all routes, containers safety stocks at primary ports as well as optimum empty containers reposition strategy based on market's requirement, all with purpose to avoid potential empty containers shortage. Unbalanced container turnover between inbound and outbound is a global issue in the shipping industry. A very common method applied by shipping operators in balancing supply and demand is repositioning excess containers to deficit areas. Determination of total container inventory begins with the calculation of safety stock of container inventory in Surabaya and Jakarta as a demand location port. Main parameter forming the calculation model is forecast cargo at home base port per route, service schedule as well as swiftness of cargo stuffing and stripping. Furthermore, determining the best routes combination shall reduce amount of container inventory. Calculation model of producing total container inventory which should be provided in 2018 is 46,382 TEUs while total existing NSC's inventory in 2018 is 48,567 TEUs. From the total existing inventory, 2,516 TEUs turned out to be inactive (idle) for more than 30 days, meaning the active ones were 46,051 TEUs. From this comparison, calculation model is able to describe existing condition at $99.3 \%$. Using the same model, a change in route combination with a pendulum nusantara service was carried out, which resulted in 968 TEUs reduction of container potential and reduction of one vessel allocation. This leads to potential efficiency of IDR 40,624,648,190 (forty billion six hundred twenty four million six hundred forty eight thousand one hundred and ninety Rupiah) for operational of year 2018.
\end{abstract}

Keywords-Stock Reposition, Minimum Stock Level, Pendulum Nusantara, Inventory Management.

\section{INTRODUCTION}

The main challenge in sea transportation in island countries like Indonesia is the length of inter-island spans and the imbalance of inter-island demand and supply positions. Trade flows in western Indonesia, especially Java, are far greater than in eastern Indonesia. Distances between ports, economies of scale, trade imbalances between inbound and outbound, type of goods, competition

\footnotetext{
${ }^{1}$ Heri Cahyono and I Nyoman Pujawan are with Department of Management Technology, Institut Teknologi Sepuluh Nopember, Indonesia. Email: pujawan@ie.its.ac.id.
}

and characteristics of each port, cause differences in freight costs using ocean freight.

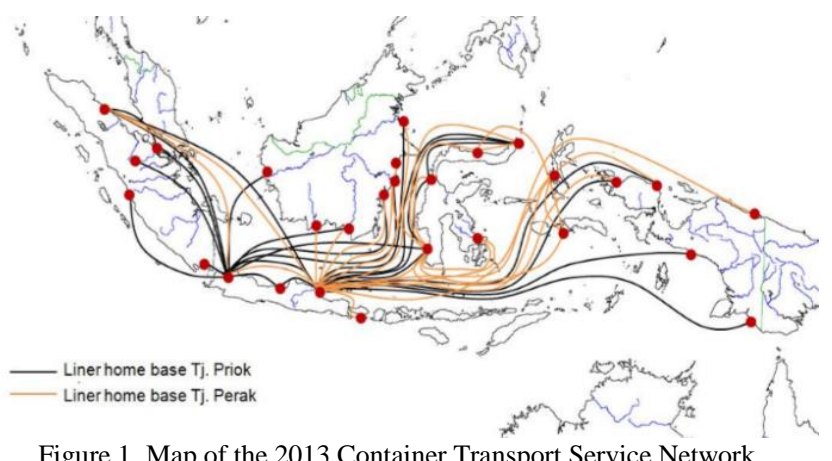

Figure 1. Map of the 2013 Container Transport Service Network

Figure 1 is taken from the Strategic Plan of the Directorate General of Sea Transportation 2015 - 2019. Based on Figure 1, it can be seen that the main movement of cargo on domestic shipping routes comes from the ports of Surabaya and Jakarta, which then spread throughout Indonesia.

The volume or number of containers distributed annually increases by around $6 \%$ to $8 \%$. The increase in inter-island trade volume in containers and sea transportation is surely encourage increased competition between shipping lines. Efficient in terms of operations is the keyword to win the competition. Container repositioning cost is a significant cost that must be borne by the shipping lines.

National Shipping Company (NSC) as one of national shipping lines, is one of the important parts in goods transportation services which connect between islands in Indonesia. In 2018, NSC operates around 50 vessels of various sizes and more than 48,000 TEUs of containers. The main cargo source in Indonesia comes from Java Island with 2 major ports, Jakarta and Surabaya.

Based on data in Table 1 loading and discharge volume in 10 major ports of NSC route shows that the two largest ports on the domestic routes of NSC are Surabaya and Jakarta, where the outbound cargo is far greater than the incoming Inbound port. According to [1], container turnover basic concept starts from taking empty containers from shipping depots at loading port, then stuffing the cargo in the shipper's warehouse and or stuffing in the shipping depot, followed by stacking (Container Yard CY) in terminal, loading on board, vessel travel at the 
destination port or port of discharge, discharge from vessel to $\mathrm{CY}$ in discharging terminal, followed by stacking at the shipping depot and finally cargo stripping process from the container. This process is a process that continues to rotate and then the container moves back to original port.

\section{TABLE 1.}

Full Container Volume Data (TEUS) In 2018 AT 10 MAJOR PORTS OF NSC ROUTE

\begin{tabular}{cllll}
\hline \hline No & \multicolumn{1}{c}{ Port } & Outbound & Inbound & Balance \\
\hline 1 & Surabaya & 306.569 & 122.098 & -184.471 \\
2 & Jakarta & 161.981 & 82.110 & -79.871 \\
3 & Makasar & 56.703 & 90.047 & 33.344 \\
4 & Banjarmasin & 32.959 & 62.975 & 30.016 \\
5 & Belawan & 24.962 & 63.253 & 38.291 \\
6 & Padang & 12.403 & 26.516 & 14.113 \\
7 & Kupang & 5.174 & 26.740 & 21.566 \\
8 & Bitung & 5.967 & 23.678 & 17.711 \\
9 & Palu & 11.292 & 18.055 & 6.763 \\
10 & Kendari & 7.408 & 16.491 & 9.083 \\
\hline \hline
\end{tabular}

Market growth in domestic shipping line industry is around $6 \%$ per year, increasing port capacity with infrastructure development and loading and discharge performance in several major ports in Indonesia, are mostly addressed by shipping companies with the addition of vessel loading capacity with the addition of vessels. This growth is certainly also in line with the addition of container supplies. Based on data from the last three years at NSC, the peak season conditions only occur in the fourth quarter and the rest tend to be stagnant or low season, and there is an excess of empty container inventory. So that the holding cost and storage costs of empty containers at low season are very high, because empty containers are idle and unable to generate revenue. The excess inventory of containers or the number of containers that are not optimal also affects the level of need for depots (land rent), the number of equipment operated and operational resources and handling of container movements, so that the total costs borne by shipping companies are inefficient.

\section{LITERATURE REVIEW}

\section{A. Container Management Distribution}

Container shipping companies generally have a fixed route, which connects loading port and destination port. Vessel route can be a route with two fixed ports, but it can also be a combination of several ports. Each vessel serving a particular route will always return to the original port or also be called the vessel Turn Round Voyage (TRV). The port of origin is also referred to as the home base port, where the main cargo will mostly be transferred to the destination port or loading port. In general, the port of origin for domestic routes in Indonesia comes from Java, with Surabaya and Jakarta as main ports. While other ports are supporting ports to domestic shipping routes.
Vessel that serve predetermined routes are adjusted to the need for service levels and or the number of scheduled payloads that have been planned by the marketing department. Service schedules for each route and vessel may be different, depending on the amount of cargo subject to be moved each time and route. Target service schedule, operationally set as Turn Round Voyage (TRV). The concept of calculating TRV is the time needed by each vessel from departing at the home port (port base) to returning to the original port. Home-base port of the National Shipping Company (NSC) is the port of Surabaya and Jakarta. Container shipping companies as one of the transportation service providers, shall provide cargo space on vessel as well as to provide empty containers as cargo loading area for customers.

1) Distribution Network

In the business of shipping companies, logistics main function is the distribution of containers transported by vessels from loading port to destination port. Management of container arrangements is needed on each route and every port. The main purpose of the distribution network of a shipping company is to maximize service or service to customers, while at the same time, still try to reduce distribution costs. Ensuring the availability of container stock at each port and distribution network is a necessity in the midst of uncertainty from customer demand, so that adequate safety stock is needed in anticipation of a surge in demand [2].

Hereunder detailed considerations are required to confirm distribution network structure:

1. Volume of container stocks volume at each port, by considering storage and transportation cost;

2. Venue to place primary container stocks, by considering geography (location), customers' request and cost;

3. Determine containers type and stacking venue. There are container types in shipping industry, which categorized based on customer needs. Fast moving containers type might be stacked at more than one ports while slow moving containers type might only be stacked in particular branches.

4. Containers inventory management, to control inventory in sufficient volume, in line with customers' needs and precise distribution network decision.

In a distribution network, costs are the main factor that must be considered. Based on [2], there are three main cost elements namely:

1. Transportation cost

2. Storage cost

3. Inventory cost

\section{B. Container Inventory Control}

Control of container supplies in the shipping business is one of the main things. The shipping company operations must be a major part in supporting profit contribution by still paying attention to service level aspects for customers 
and the company finances. The aim is not to make the availability of containers always available at all times without regard to the cost aspect, but to fulfill the availability of containers at a cost as efficiently as possible. The long-term profitability of the company must be translated into operational targets and financial targets that are applied to the daily operating pattern. The purpose of inventory control in supporting business activities is to optimize 3 things, namely [3]:

1. Customer service cost

2. Inventory cost

3. Operational cost

2) Stock Turnover

Stock levels in various types, not all at the same level, some are high and some are low. The purpose of inventory control is to direct the company to the right level that is influenced by the characteristics of supply and demand [3].

Below are the main factors that affect the stock turnover rate:

1. Supply stock lead time

2. Demand variability

3. Frequency of supply

4. Delivery lead time to customers

5. Supplier's reliability

6. Criticality of item

7. Stock availability from other sources

Calculation method to measure inventory management effectiveness is by calculating stock turnover or stock turn.

Stock turn over $=$ (volume of use in 1 year) $/$ (value stock inventory).

The higher stock turn over means that companies require fewer stock inventory, but still pay attention to market needs [4]. One way to increase stock turnover is to speed up containers repositioning to demand locations or shorten repositioning lead times.

3) Safety Stock

Stock is stored as inventory because goods are needed faster or require a large amount of volume. In terms of determining stock in each market location, there are some uncertainties regarding the amount needed and how much stock is stocked (safety stock). A balance between good service and low inventory costs and efficient operational costs are needed. The amount of safety stock stored as inventory according to [3], depends on the following three main factors:

1. Demand variability

2. Reliability of supply

3. Transportation process dependency

The general approach for this situations is to set the optimal stock level to meet the variability of demand from customers or markets.

Stock movements at the request and supply as well as previous data information, is very important to know to determine the optimal stock level. Stock level information must be evaluated for a certain period of time, daily, weekly or monthly. In the case of shipping company businesses, daily demand and supply information is important to know. The demand pattern can be described in certain period units in the form of histograms, so that it can be assumed to be relatively easy as a demand pattern that is normally distributed. The main parameters of the normal distribution are the average and the average width or variation. In general, the size of the variation width used is the standard deviation.

The main basis to calculate safety stock determination is the difference between actual demand and demand estimation which occur randomly. These random variations in requests are usually normally distributed. The calculation of safety stock value is done by calculating the standard deviation of demand during the lead time and a value from the standard normal distribution table that correlates with a certain probability $(Z)$. $Z$ value is usually translated into management decisions. If management sets a tolerance for deficiencies of 5 times in 100 order cycles, then the desired service level is $95 \%$, the $\mathrm{Z}$ value which correlates with the $95 \%$ service level is 1.645 .

To determine safety stock of container availability, the safety stock is determined by the interaction of two uncertainties, in this matter is in terms of lead time and demand. Then the standard deviation values used are as follows:

$$
\mathrm{Sdl}=\sqrt{ }(\mathrm{d} 2 \times \mathrm{Sl} 2+\mathrm{I} \times \mathrm{Sd} 2)
$$

Sl and Sd is the standard deviation of lead time and standard deviation of demand per period. In inventory management, safety stock is kept as minimum as possible but at the level to be able to meet market needs. To increase service levels will exponentially increase safety stock amount. If service level is still low, increasing just a little safety stock amount has given a considerable improvement. In contrary, if service level condition is already high, then effort and costs needed to increase can be greater than the benefits that will be generated. In the management of domestic shipping container movements in NSC, safety stock is more determined by the variability of demand, where the lead time tends to be constant, because every day there is always a movement of supply to the main port, the effect of the concept of balance container back to home base. Besides lead time from supply side, related to empty container production from ex repair, and ex stripping tend to be fixed. So that the Safety stock (SS) can be defined as follows:

$$
\text { Safety stock }=\text { Z x S1 x Average demand/day }
$$

In determining total container inventory needed by shipping companies, it is also necessary to know the distribution pattern of goods loaded, from the origin port to the destination port. The main ports of origin of goods in Indonesia are from Java, with the main loading port in Surabaya and Jakarta. By knowing safety stock in the main ports in Surabaya and Jakarta as the main cargo of shipping business in Indonesia, the next calculation is to know the 
length of service schedule for each route (TRV) and free time at the loading and discharge port which is a facility provided to the customer. Complete formulation of calculation of total container inventory is as confirmed hereunder:

Total Inventory at Main Port

$$
\begin{aligned}
& \sum \operatorname{Iin}=\left(\sum \text { in } \mathrm{Z} \times \mathrm{Sl} \times \mathrm{D} / \text { day }\right) \times \sum \mathrm{ij} \text { pij } \times \sum \mathrm{ij}(\mathrm{Fti}+ \\
& \mathrm{Ftj}+\mathrm{TRVij}+\mathrm{e})
\end{aligned}
$$

$\mathrm{Z} \quad$ : Value related to service level, in normal distribution

S1 : Standard deviasi leadtime supply

D : average Demand

Pij : Demand volume proportion/route at main port

Fti,j : Container Freetime per port

Container usage freetime per port

TRV : Vessels operations' time in one service schedule cycle

e : Service schedule performance or TRV deviation

By limiting number of main ports $I=1,2 . . n>0$, and between ports at main ports $I=1,2, \ldots . j>0$

Vessel Operations Performance and Container Loading \& Discharge Activities

In shipping companies, vessel operations performance and container loading \& discharge activities are major points to understand vessel service performance. Please refer to hereunder details in regards to major performance subject to be measured:

1. Turn Round Voyage (TRV), is a measure toward shipping company vessel's performance on each predetermined route. TRV calculation is the time taken for the vessel to start from the original port (main port or home base port) until it returns to the original port. For the case in the National Shipping Company (NSC), home base ports were set by Surabaya and Jakarta as the largest markets of origin. Each $1 \mathrm{TRV}$ is given a different number in consecutive manner, as according to the order of service schedule in each route.

2. Port Stay, is a measure vessel performance in the port area, starting from vessel arrival until vessel departure.

3. Berthing time, is vessel performance measure related to the how long vessel berth at the wharf, to carry out container loading and discharge activities. This performance measure is calculated from the anchorage to the time vessel taken off from wharf.

4. Box Ship Hour (BSH), is a measure of container loading and discharge productivity performance in box per hour. This calculation is obtained by dividing container loading and discharge volume with vessel's berthing time.

Understanding distribution network or vessel route, vessel operating performance and costs arising from vessel and container movements, shipping companies must determine the right route network, service frequency for each route and combination between ports.
Empty container repositioning movement is inseparable from full container movement. The main principle of container movement is balance reposition, where if the vessel departs from port of loading A to port B with volume $\mathrm{X}$, the vessel must return to the original port with the same volume of $\mathrm{X}$ containers. A good operational performance shall also reduce the time of container use in each route.

4) Combining Distribution Route

Empty container turnover occur due to the effect of imbalance in full container rotation. In this regards to this matter, shipping companies must make decisions about cargo routes, service schedules expected by the market, direct service or transshipment, allocation of appropriate vessel capacity and others. Before network route modeling was made, several assumptions in this study were made as mentioned hereunder:

1. Containers in TEUs (20 feet equivalent units) where the size of 1 x $40 \mathrm{ft}$ is equivalent to $2 \times 20 \mathrm{ft}$.

2. After containers discharged at destination port, it can be used again to another port or reposition empty containers. Trucking transportation activities at destination port is ignored.

3. Distribution network and vessel allocation is assumed at particular period.

The distribution network model that connects locations according to the unique characteristics of the problem, can be formulated as follows:

1. Repositioning of goods from several sources to destination venue using most minimum cost

2. Goods from each source is able to supply fixed volume while each destination has fixed demand quantity.

\section{Methodology}

\section{A. Initial Observation}

NSC initial observation in this study was to observe vessels' network pattern developed by NSC, so that a basic map of existing network patterns was obtained. This initial process is to determine the position of main loading and destination port. Next is observing number and movement of cargo repositioning from and to the main port. Based on the initial NSC observation based on direct interviews with NSC operations section, there are a number of departures from Surabaya per month, around 90 calls (vessel departures) and 30 calls from Jakarta. The total vessel trips from Surabaya and Jakarta are around 120 calls per month or almost 1,500 calls per year from Surabaya and Jakarta.

Regarding the above, currently there is no specific formulation used in NSC, to calculate the level of container needs in all distribution network patterns throughout Indonesia. However, calculation of container utilization trend ration is carried out periodically per month, followed by the trend starting from 5 years backwards. The formula of utilization ratio is as follows: 


$$
\text { Container Utilization Ratio }=\sum \mathrm{Xi} \div \sum \mathrm{Ii}
$$

$\sum \mathrm{Xi}$ is the total load of months $\mathrm{i}$ and $\sum \mathrm{Ii}$ is the total inventory in month I, so that the average utilization ratio per month is obtained and the trend is followed every year along with the records that occur in each period. The results of this calculation are only to indicate container use, so that if there is a plan to increase the volume of cargo from marketing department in the operational budget preparation process every year, then the level of utilization Ratio assumed to be achieved, the required inventory amount is obtained. Ratio only describes the previous conditions. This has yet can be used for future planning simulations, if there are changes in routes between ports and or the opening of new routes.

\section{B. Containers Requirement Calculation Formula}

At this stage, the calculation formula begins by looking at the map of outbound and inbound loads positions in all ports which are part of the pattern of NSC network. The biggest imbalance is defined as the main origin port, which must be kept at an empty container level every day. The level of availability at the main port of origin is determined by the calculation of safety stock by paying attention to the optimal lead time supply and service level. The calculation of safety stock is to obtain a minimum daily inventory volume that must be provided to meet customer demand.

After calculating daily safety stock container in the demand location port, a checking process is needed with data on withdrawals and / or daily needs of the customer, at the main ports of Surabaya and Jakarta.

The second stage, after getting the minimum daily inventory at the ports of Surabaya and Jakarta in each period, it is necessary to calculate the proportion of outbound cargo on each route or service schedule from Surabaya and Jakarta home base ports. The outbound load from the Surabaya and Jakarta home base ports is a function of the demand for container inventory, so that the right supply can be determined on each route.

The third stage that needs to be known is the Turn Round Voyage (TRV) of each service schedule from Surabaya or Jakarta that has been determined by the Trade Department in NSC. TRV function is the function of the length of the container used in one cycle time from port of origin and return to port of origin. The longer the TRV from a service or route, the more container supplies needed.

The fourth stage is to calculate the average length of container use on each route and in each port. There are 2 calculation patterns for this stage, which are using free time given by the Trade Department to each customer on each route or calculating the actual speed of stripping and stuffing loads to and from the container. Stripping speed and stuffing on each route and port reflect customer speed in using containers. The speed of container use on each route and port is also determined by the load characteristics and weather conditions, equipment and the environment at concerned local port.

The fifth stage is to determine the tolerance of the formulation in the four stages mentioned above, assumed as tolerance calculation and can be approached by the percentage of TRV achievement between the target and realization. The approach of tolerance to TRV is reasonable, because this is strongly influenced by nonoperational and operational factors, such as weather, availability and reliability of ships and equipment at the port, productivity of loading and discharge at ports, local port authority policies and others, where fluctuating nature changes.

The last step after paying attention to the combination of existing distribution networks is to try to create several new combinations that combine the main ports, especially the 4 main ports of Surabaya, Jakarta, Belawan and Makassar. This combination aims to optimize vessel capacity usage and reduce the use of container quantities, reducing supply lead-time at the main port and of course it is expected to get the most optimal slot cost.

\section{Evaluation of Existing Inventory Formula}

Calculation results according to the above formula need to be compared to the current condition of the existing inventory. If the results of the calculation of container inventory show a decrease in the amount of inventory and repositioning costs for containers, the proposed scenario can be used as a basis for the implementation of determining the calculation of container inventory in NSC, and can be used as the basis of the company regarding the size of subsequent operations. In this calculation, what is meant by inventory is the amount of inventory of active containers that supports the company's performance in generating revenue at an efficient cost.

\section{RESULT AND DisCUSSION}

\section{A. Operational Pattern and Route Network}

NSC divides the shipping route network into two operational zones, namely the western operational zone centered in Jakarta and the eastern operational zone centered in Surabaya. If grouped according to their operational area, the Jakarta Port is the main connecting port of the western region with the following routes: Jakarta-Belawan-Jakarta, Jakarta-Padang-Jakarta, JakartaTanjungpinang-Jakarta, Jakarta-Banjarmasin-Jakarta, Jakarta-Makassar- Jakarta, Jakarta-Surabaya-GorontaloBitung-Jakarta.

Surabaya Port as the main hub of the eastern region with the following routes: Surabaya-Banjarmasin-Surabaya, Surabaya-Sampit-Surabaya, Surabaya-Kumai-Surabaya, Surabaya-Balikpapan-Surabaya, Surabaya-SamarindaSurabaya, Surabaya-Tarakan-Surabaya, SurabayaMakassar-Surabaya, Surabaya-Kendari-TangkiangKendari-Surabaya, Surabaya-Palu-Surabaya, Surabaya- 
Toli-Surabaya, Surabaya-Makassar-Ambon-Surabaya, Surabaya-Benoa-Surabaya, Surabaya-Maumere-ReoSurabaya, Surabaya-Ende-Surabaya, Surabaya-KupangSurabaya, Surabaya-Wini-Dili-Surabaya, SurabayaLembar-Surabaya.

\section{B. Containers Turnaround from and to Main Port (Home Base Port)}

Surabaya and Jakarta are the main intersection of domestic container movements in Indonesia. The return volume proportion to Jakarta on average is $51 \%$ full container and $49 \%$ is empty container, while the return volume proportion to Surabaya is $39 \%$ full container and $61 \%$ empty container. It is interesting to note that the payload to Surabaya is a much smaller percentage than the return load to Jakarta. But in proportion, the average full load out of Surabaya per month is far greater than that of Jakarta, which is about $65 \%$ full load from Surabaya (average per month 25,248 TEUs) compared to $35 \%$ full load from Jakarta (average per month of 13,483 TEUs).

In regulating domestic empty containers in Indonesia, it can be said that the ports of Surabaya and Jakarta are demand location ports and other ports are supply location ports. In general, the concept of regulating empty containers in the shipping industry is balance reposition, where the number of containers loaded from the origin port will be the same as the number of containers returning to the original port, especially in the home base port. Full containers movement out of Surabaya and Jakarta ports, can be used as the basis for demand or demand data on empty container needs that must be provided to meet customer demand and data on total container movements per month for total full and empty containers can be used as container data in Surabaya Jakarta.

\section{Containers Volume from Surabaya and Jakarta Main Ports and Minimum Stock Determination}

Surabaya and Jakarta as the place of origin of the main container cargo for Indonesia's domestic needs, both in the western region and the eastern part of Indonesia, where in general the port of Jakarta meets the needs of the western region and the port of Surabaya meets the needs of the eastern region. But at some domestic routes are intersect from Surabaya and Jakarta and or transshipment in Surabaya, as a wider trading gate in the eastern region for NSC shipping routes. Load composition from Surabaya and Jakarta, is quite diverse both in terms of the volume of goods and the types of goods loaded in containers.

In this study, it was determined as a location port demand that must always be met with container needs per day. Container needs at all times in Surabaya and Jakarta, as a basis for determining the amount of container inventory at each route and total inventory to fulfill all shipping routes at NSC. In this study, the basis for determining empty containers minimum stocks in Surabaya and Jakarta is the data of full container movements every month. Based on Surabaya Out and Jakarta Out load data per month in 2018, the initial data is obtained for calculating the minimum stock of containers per month and per day with several service level variants as follows:

$$
\text { Safety Stock }=\text { Z x Sl x Average demand }
$$

TABle 2. Monthly and Daily Basis SaFeTy Stock Calculation IN SURABAYA AT 2018

\begin{tabular}{ccccc}
\hline \hline $\begin{array}{c}\text { Average per Month } \\
\text { 2018 (TEUs) }\end{array}$ & $\begin{array}{c}\text { Service } \\
\text { Level }\end{array}$ & Coefficient & $\begin{array}{c}\text { Safety } \\
\text { Stock/month }\end{array}$ & $\begin{array}{c}\text { Safety } \\
\text { Stock/day }\end{array}$ \\
\hline & $80 \%$ & 0,84 & 21.249 & 885 \\
25.248 & $85 \%$ & 1,04 & 26.168 & 1.09 \\
& $90 \%$ & 1,28 & 32.357 & 1.348 \\
& $95 \%$ & 1,64 & 41.53 & 1.73 \\
& $98 \%$ & 2,05 & 51.854 & 2.161 \\
\hline \hline
\end{tabular}

During peak season conditions in the second semester of each year in Surabaya, the withdrawal of empty containers per day ranges from 1,000 TEUs to 1,200 TEUs. With this condition, the calculation of safety stock per day is carried out with an optimization test with a near optimal change in service level. Based on these conditions, service levels that are close to optimal are in the service level range of $85 \%$ to $90 \%$. As comparison data from the safety stock calculation, daily container withdrawal data in Surabaya was taken from January 1, 2018 to data March 13, 2019 or in the range of 433 days of container withdrawals. With $85 \%$ service level and 1,090 TEUs empty safety stock values, there are 24 days of empty container shortage events compared to 433 days of empty container withdrawal samples, or equivalent to $6 \%$ of empty container shortage events. With the iteration process calculation of service level optimization to get $0 \%$ shortage value, with the help of the excel 2013 What-if Analysis software formulation, the service level value of $88 \%$ is obtained and the daily safety stock value is 1,223 TEUs. With the results of this calculation, it can be said that the minimum stock of empty containers that must be available in Surabaya in order to avoid shortage conditions throughout 2018 is 1,223 TEUs.

TABLE 3.

MontHLy AND DAILY (TEUs) SAFETy StOck CALCULATION RESUlt IN JAKARTA AT 2018

\begin{tabular}{ccccc}
\hline \hline $\begin{array}{c}\text { Average per Month } \\
\text { 2018 (TEUs) }\end{array}$ & $\begin{array}{c}\text { Service } \\
\text { Level }\end{array}$ & Coefficient & $\begin{array}{c}\text { Safety } \\
\text { Stock/month }\end{array}$ & $\begin{array}{c}\text { Safety } \\
\text { Stock/day }\end{array}$ \\
\hline & $80 \%$ & 0,84 & 11.347 & 473 \\
& $85 \%$ & 1,04 & 13.974 & 582 \\
13.483 & $90 \%$ & 1,28 & 17.279 & 720 \\
& $95 \%$ & 1,64 & 22.177 & 924 \\
& $98 \%$ & 2,05 & 27.690 & 1.154 \\
\hline \hline
\end{tabular}

Using the same methodology to have daily containers minimum stock in Jakarta.

Withdrawal of empty containers per day in Jakarta in the period 2018 and up to quarter 12019 ranges from 550 TEUs to 650 TEUs. With this condition, the calculation of 
safety stock per day is carried out with an optimization test with a near optimal change in service level. Based on this condition, the service level that is close to optimal is in the service level range of $85 \%$ to $90 \%$. As comparison data from the safety stock calculation, daily container withdrawal data in Surabaya was taken from January 1, 2018 to data March 13, 2019 or in the range of 433 days of container withdrawals. With a service level of $85 \%$ and a safety stock value of empty containers of 582 TEUs, there are 16 days of empty container shortage events compared to 433 days of empty container withdrawal samples, equivalent to $4 \%$ of empty container shortage events.

With the iteration process calculation of service level optimization to get $0 \%$ shortage value, with the help of the excel 2013 What-if Analysis software formulation, the service level value of $89 \%$ is obtained and the daily safety stock value is 686 TEUs. With the results of this calculation, it can be said that the minimum stock of empty containers that must be available in Jakarta to avoid shortage conditions throughout 2018 is 686 TEUs.

Based on the calculation of empty containers minimum stocks in daily basis in Surabaya and Jakarta, minimum total container obtained so as not to occur shortages throughout 2018 is 1,223 TEUs (Surabaya) plus 686 TEUs (Jakarta) of 1,909 TEUs. This amount is the daily empty container needs that are actively operating to meet customer needs in the two main ports of Surabaya and Jakarta.

\section{Container Loads Proportion per Route from Surabaya and Jakarta}

Each route, which starts from Surabaya and Jakarta home base ports, has different cargo and volume characteristics. Information regarding volume of cargo per route is one of the important factors for determining the allocation of vessels on each route. Large cargo volumes will of course be allocated with larger vessel sizes and or more frequent service frequency. Some routes are a combination of several port services and some other routes are liner services that only connect two ports, namely loading port and destination port.

\section{E. NSC Domestic Route Service Schedule Performance in 2018}

One of the main performance measures of the shipping industry is ship schedule services, also referred to as shipping, is Turn Round Voyage (TRV). The TRV performance measure is the target set for the ship to serve a route with a certain time. The TRV calculation is that the ship departs from the homebase port at time $t$ until the ship departs again at $t+1$. Suppose the Surabaya-MakassarSurabaya route is set to TRV 7 days (weekly schedule), then the ship must depart from the home base port on the same day every week. TRV performance measures have many implications in the shipping industry, such as the accuracy of the schedule given to customers, charter hire or boat rental fees and container inventory requirements. The longer the ship sails and or exceeds longer than the set target, the container needs will increase, and the movement and utilization of containers will be lower, besides the ship costs will also be higher.

\section{F. Stuffing and Stripping Performance \& Loading and Discharge Activities at NSC Ports Route}

The use of containers as one of goods transportation modes between the origin of the goods to the destination of delivery, starts from taking empty containers from the shipping depot at the loading port, then the stuffing process loads at the shipper's warehouse or stuffing in the shipping depot, followed by stacking or stacking on the Container Yard (CY) terminal, loading on board, boat trip at the destination port or port of unloading, unloading from the ship to the unloading terminal CY, continued stacking at the shipping depot and finally the process of stripping cargo from the container. This is in accordance with the basic concept of container turnover according to [1].

Stuffing activity is to put items into containers at the port of loading and stripping, is the expenditure of goods from containers at the loading port. In general, free time given by domestic shipping companies or container use starts to release empty containers until full status after stuffing and continues to load on the ship is 5 days, as well as free time at the port unloading, start loading and unloading from ships and empty and back empty the container at the shipping depot is 5 days. However, in some routes or ports this policy can be different, taking into account the conditions of competition with other shipping and or customer characteristics and or the volume of cargo loaded or unloaded by each customer.

As the purpose of this study is to obtain the optimal total inventory of containers, then for the main ports of Surabaya and Jakarta, the effect is the length of containers used starting with the release of empty containers to customers to full status containers and then loading on board. While the port for loading and unloading is the length of container used to start unloading from the top of the ship to empty containers after stripping. The payback to Jakarta is only $51 \%$ of the full and 39\% conditions of the return charge to Surabaya in full condition and the rest is empty containers. Based on 2018 data processing at NSC, data on speed stuffing up to loading on ships in Surabaya and Jakarta as well as data on speed stripping at loading ports outside Surabaya and Jakarta.

TABLE 4.

STUFFING TO LOAD TIME IN SURABAYA AND JAKARTA AT 2018

\begin{tabular}{cccc}
\hline \hline Port & Empty to Full (day) & Full to Load (day) & Total (day) \\
\hline Surabaya & 2,2 & 3,0 & 5,2 \\
Jakarta & 2,0 & 2,0 & 4,0 \\
\hline \hline
\end{tabular}


TABLE 5.

StriPing PERFoRMANCE AT Discharge PoRT -2018

\begin{tabular}{lc}
\hline \hline Port & Full to Empty (day) \\
\hline Lembar & 10,63 \\
Ambon & 4,14 \\
Banjarmasin & 5,25 \\
Bitung & 6,22 \\
Belawan & 8,57 \\
Benoa & 6,68 \\
Balikpapan & 8,08 \\
Dili & 24,91 \\
Gorontalo & 12,07 \\
Kendari & 8,21 \\
Kupang & 9,46 \\
Makassar & 5,36 \\
Maumere & 6,46 \\
Kumai & 8,56 \\
Pontinak & 4,15 \\
Palu & 13,44 \\
Reo & 19,52 \\
Sampit & 6,11 \\
Semarang & 5,73 \\
Samarinda & 14,00 \\
Tangkiang & 13,77 \\
Toli & 14,06 \\
Tarakan & 10,05 \\
Wini & 8,25 \\
\hline \hline
\end{tabular}

Based on Table 4 and Table 5, it can be seen that for the condition of container use at the loading port of Surabaya and Jakarta, there are relatively no problems and are still within the limits of the free time of 5 days given by NSC to the customer. Whereas the conditions at the loading port outside the ports of Surabaya and Jakarta, almost all of them exceed the free time in general, which is given to the customer, which is 5 days after the container is unloaded, except in Ambon port faster than free time. The highest condition or at the latest stripping is in Dili. The slower the container is returned to the shipping company, the more containers that must be provided by the shipping to fulfill the next loading demand on the same route, and this will of course have an effect on increasing the container inventory.

\section{G. Existing Routes Containers Inventory Calculation in 2018 and Main Variable}

Based on the flow chart for calculating container requirements, the first is the determination of the demand location port and based on outbound and inbound cargo data, Surabaya and Jakarta are the main ports that require empty containers that must always be fulfilled. The next step is determining the minimum daily stock of containers in Surabaya and Jakarta, as calculated in Chapter 4.3, where based on 2018 cargo out data from Surabaya, the minimum daily stock is 1,223 TEUs with $88 \%$ service level and 686 TEUs in Jakarta with service level 89\%. The formulation used in determining the total inventory, in general, is a daily stock inventory in the main port multiplied by the proportion of cargo per route from the main port and multiplied by the function of the total container usage at the loading port, on board and at the port of loading and performance or achievement of service schedule operations, with a summary of formulations as explained in point 2.2.2 of this paper.

Based on the calculation on Table 6, the total container requirements that are actively used in the NSC companies in 2018, 30,527 TEUs on the Surabaya route are added with 15,855 TEUs on the Jakarta route totaling 46,382 TEUs. The total actual inventory of containers in 2018 is 48,567 TEUs. Not all containers owned in 2018, actively engaged in supporting the performance of NSC, there are a number of cases where idle containers are quite long over 30 days. The average empty container that does not move more than 30 days in 2018 is 1,636 TEUs and there are 881 TEUs of full container which do not move above 30 days due to various cases both in the shipper, consignee, at the loading port or loading port.

With this comparison, the calculation model built more or less reflects the actual conditions in 2018, where container calculation data is almost the same as the number of active containers in the range of 46,000 TEUs, so the model used can be used as a plan to procure the next container inventory according to forecast payload from the marketing department for the next period. In addition, it can also be seen what variables affect the needs of containers on each route. TRV's service performance operation schedule is the main control of the NSC operations section to achieve the predefined TRV target, in addition to controls related to container use at loading ports and loading ports, and marketing free time on each route.

\section{H. Total Containers Inventory Calculation Effect to Pendulum Route Changes}

Based on the calculation of the total demand for container inventory that is actively used in the NSC companies in 2018 is 46,382 TEUs, with a change in the Belawan-Jakarta-Makassar pendulum nusantara route, it has the potential to directly reduce the need for 958 TEUs container supplies. If it is assumed that the cost of 1 TEUs of empty containers is USD 2,000, then the potential cost reduction from the purchase price of empty containers is USD 1,916,000, not including transportation costs and import duty taxes on imported container goods. Assuming the exchange rate per May 17, 2019 is IDR 14,510, then the potential reduction in costs from the purchase price of empty containers is Rp. 27,801,160,000 (twenty-seven billion eight hundred one million one hundred thousand rupiah). If it is assumed that 958 TEUs are a container discount deduction, the rental price for container size of 20 feet is currently around USD 0.7 / day with a minimum 
rental duration of 1 year (365 days), so the deduction of container rental costs is IDR 3,551,598,190/year (three billion five hundred fifty-one million five hundred and ninety-eight thousand one hundred and ninety rupiah per year).

With the pendulum nusantara concept that combines two routes into one combination of routes and from the total allocation of four ships to only 3 ships with the same capacity, the savings are not only in terms of reducing inventory inventories, but also reducing the rental of one ship. Rent a boat for a capacity of 1,000 TEUs, if it is assumed to be USD 7,000 / day, then the vessel's operational savings in one year (365 days) is IDR 37,073,050,000 (thirty-seven billion seventy-three million fifty thousand rupiah).

Based on Table 7, total potential reduction in costs with an alternative service schedule of Belawan-JakartaMakassar pendulum in one year assuming a reduction in rental costs for 958 TEUs containers and a reduction in rental of one vessel unit, is IDR 40,624,648,190 (forty billion six hundred twenty-four million six hundred fortyeight thousand one hundred and ninety rupiah).

\section{CONCLUSION}

The process of determining the empty container inventory starting from determining the demand location port or the full container sending port from Surabaya and Jakarta, then calculating the minimum inventory of empty containers per day in the two main ports based on full container shipments realization data in 2018 with an optimal safety stock calculation method service level. From the calculation results, the minimum empty containers that must be provided in Surabaya per day in 2018 are 1,223 TEUs and in Jakarta as many as 686 TEUs. To calculate the total inventory of containers to serve all NSC routes in 2018 , the main variable that affects is the proportion of the cargo per route from the main port and the length of the container used both at the loading port, on board and in the loading port, based on the formulation written in this study. The total container inventory to service the marketing needs of the NSC Company in 2018 is 46,382 TEUs. The number of existing containers owned by NSC in 2018 is 48,567 TEUs. The total NSC containers in 2018 there were 2,516 active TEUs for more than 30 days (idle). Idle containers for more than 30 days as many as 881 TEUs of full containers and 1,635 TEUs of empty containers, so that the active mobile container category was 46,051 TEUs. The number of active containers in 2018 is almost the same as the calculation formulation model written in this study, which is around 46,000 TEUs or $99.3 \%$ accordingly. So that it can be said that the container inventory calculation model can describe the existing conditions in 2018.

Based on the results of calculations in this study, the main variables that affect the level of inventory of containers are as follows:

1. Safety stock or minimum empty container inventory per day in Surabaya and Jakarta ports with a service level of around $89 \%$.

2. Vessel schedule services per route or Turn Round Voyage (TRV) of ships, or the length of the vessel sailing in one round home base out route back to home base both Surabaya and Jakarta.

3. The use of containers at the loading port from the start of the pick up empty container to the full container status and loaded on the vessel and the use of containers at the loading port, starting from vessel loading to empty containers.

4. Measures of performance in ports that affect the speed of loading and unloading of ships and possible changes to service schedules.

By considering these 4 variables, changes and / or mergers of two routes are made into one combination of the Belawan-Jakarta-Makassar pendulum nusantara service route. Based on the calculation results, the efficiency of container use is 968 TEUs and the reduction of one ship unit allocated previously with the value of potential efficiency of IDR 40,624,648,190 (forty billion six hundred twenty-four million six hundred forty-eight thousand one hundred and ninety rupiah) for one operational year 2018.

Changes in vessel route patterns with the BelawanJakarta-Makassar pendulum nusantara service also change the repositioning pattern of containers, from the previous repositioning of containers from Belawan can only be via Jakarta and Surabaya, also can directly go to Makassar as one of the major ports in Eastern Indonesia. This certainly accelerates containers movement. Based on the results of calculations, with the pendulum service, the inventory level of containers can be reduced by 958 TEUs, or nearly equivalent to 1,000 TEUs, so that container supplies in 2018 can be suppressed in the range of 45,000 TEUs of active containers. 
The $1^{\text {st }}$ International Conference on Business and Management of Technology (IConBMT)

TABLE 6.

CONTAINER INVENTORY CALCULATION FOR JAKARTA AND SURABAYA ROUTE - 2018

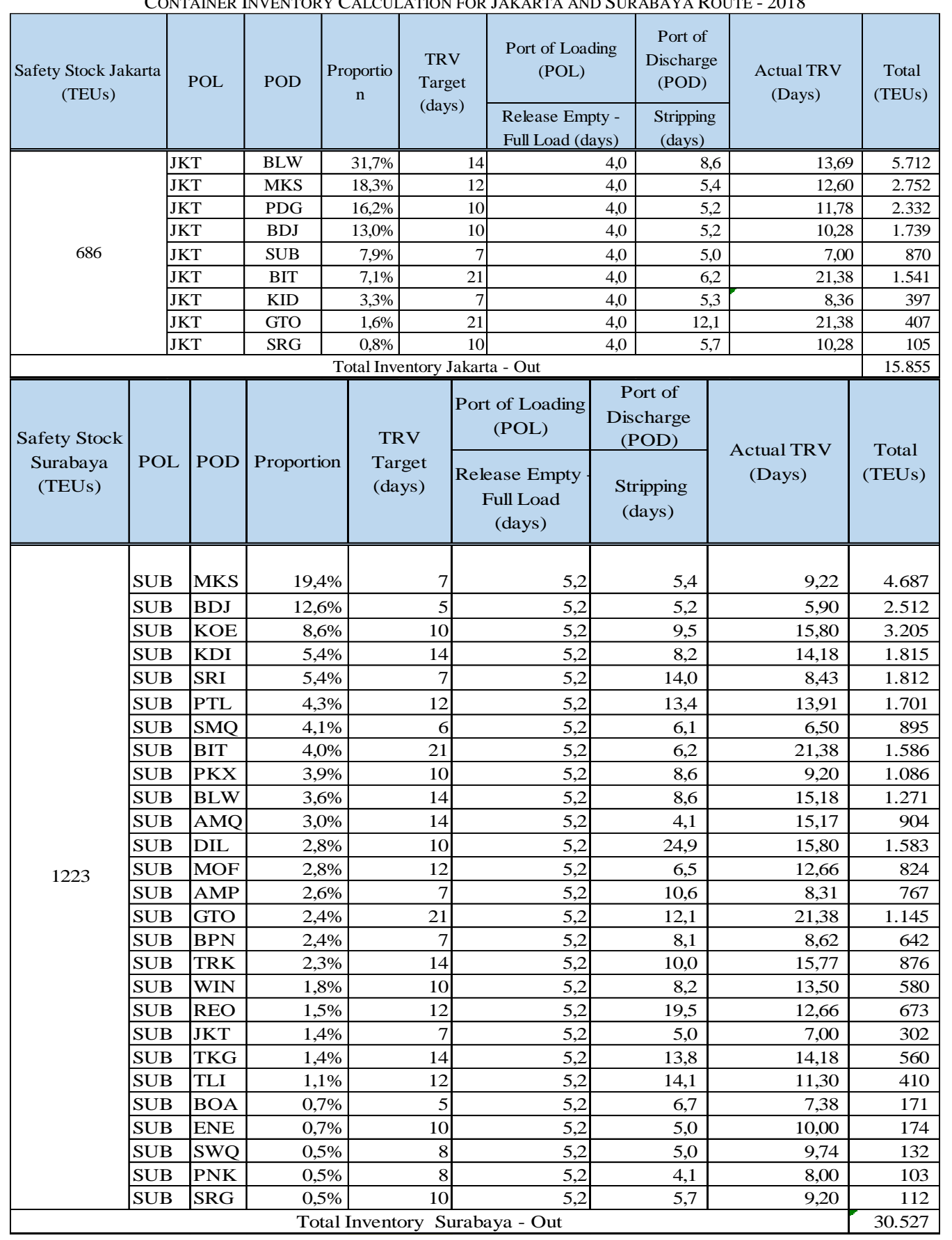

TABLE 7.

Potential Container AND Vessel Cost REDUCTION

\begin{tabular}{|c|l|r|r|r|}
\hline Reducing Container Inventory & Asumtion & Price (USD) & Kurs (IDR) & Cost per Year (365 days) \\
\hline 958 TEUs & Purchase & 2.000 & 14.510 & 27.801 .160 .000 \\
\hline 958 TEUs & Lease & $0,7 /$ day & 14.510 & 3.551 .598 .190 \\
\hline & & & & 37.073 .050 .000 \\
\hline Reduce 1 Vessel & Lease & $7000 /$ day & 14.510 & 40.624 .648 .190 \\
\hline \multicolumn{4}{|l|}{ Reducing Total Cost per Year }
\end{tabular}


The $1^{\text {st }}$ International Conference on Business and Management of Technology (IConBMT)

August 3rd 2019, Institut Teknologi Sepuluh Nopember, Surabaya, Indonesia

\section{REFERENCES}

[1] R. Epstein et al., "A strategic empty container logistics optimization in a major shipping company," Interfaces (Providence)., vol. 42, no. 1, pp. 5-16, 2012.

[2] J. W. Toomey and E. L. Magad, Inventory Management: Principles, Concepts and Techniques. Boston, MA: Springer US, 2000.
[3] T. Wild, Best Practice in Inventory Management. Cambridge, Ontario: Woodhead Publishing Ltd, 1997.

[4] T. J. Goldsby and R. Martichenko, Lean Six Sigma logistics: Strategic Development to Operational Success. Boca Raton, Florida: J Ross Publishing, Inc, 2005. 